\title{
FGFR2 Gene Rearrangement
}

National Cancer Institute

\section{Source}

National Cancer Institute. FGFR2 Gene Rearrangement. NCI Thesaurus. Code C153241.

A molecular abnormality indicating rearrangement of the FGFR2 gene. 